\title{
Influence of Surface Modification of Alumina on Improvement of Wetability in Aluminium Matrix Composite
}

\author{
Alireza Samiee, ${ }^{1}$ Mohammad Hosein Bina, ${ }^{1,2}$ and Mahmood Meratian ${ }^{1}$ \\ ${ }^{1}$ Department of Materials Engineering, Isfahan University of Technology, Isfahan 84156-83111, Iran \\ ${ }^{2}$ Department of Advanced Materials and New Energies, Iranian Research Organization for Science and Technology, \\ Tehran 3353-5111, Iran \\ Correspondence should be addressed to Alireza Samiee; ali_samiee@ma.iut.ac.ir
}

Received 24 October 2013; Revised 26 January 2014; Accepted 16 February 2014; Published 19 March 2014

Academic Editor: Tao Zhang

Copyright @ 2014 Alireza Samiee et al. This is an open access article distributed under the Creative Commons Attribution License, which permits unrestricted use, distribution, and reproduction in any medium, provided the original work is properly cited.

In this research, aluminium powder (50 wt $\%)$ and alumina $(50 \mathrm{wt} \%)$ were first milled at a specific ball-to-powder ratio in a highenergy planetary mill at different times to manufacture $\mathrm{Al}_{-} \mathrm{Al}_{2} \mathrm{O}_{3}$ composite. Then, the capsules of powdery composites (Al$\left.\mathrm{Al}_{2} \mathrm{O}_{3}\right)_{\mathrm{CP}}$ produced at the milling stage were added to aluminium melt and cast through ex situ. Scanning electron microscope SEM was used to study the morphology of the capsules and the microstructure of the produced composite. The percentage of powdery

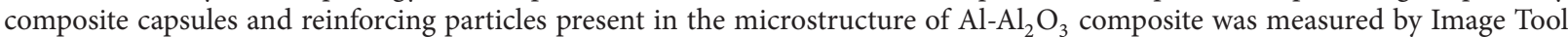
software. The results of the tests showed that, by optimizing the milling time to 5 hours, the alumina particles are sufficiently placed in the matrix of the capsules; on the other hand, alumina particles are also properly coated with aluminium powder. When these capsules are added to aluminium melt, the rate of the wetting of alumina particles greatly increases and accordingly the percentage of the reinforcing particles in the cast composite matrix increases dramatically. By surface modification and accordingly increasing percentage of $\mathrm{Al}_{2} \mathrm{O}_{3}$, the tensile strength increases and the tensile strength of the composites is higher than that of the matrix alloy.

\section{Introduction}

Some of the materials requested in the modern industries cannot be utilized by monolithic materials. Therefore, composite materials have been developed [1]. Particle reinforced aluminium matrix composites have constructively changed in the last few years, in order to decline the weight of components in structural applications and to positively make their mechanical behaviour and physical properties different [2]. Due to their light weight, high strength, and suitable wear resistance properties, aluminium matrix composites are considered as a group of advanced materials among these composites $[3,4]$. Owing to their unique mechanical properties, alumina-aluminium composites enjoy special applications in different industries $[5,6]$. There are several different methods for the production of alumina-aluminium composites. These production methods can be divided into three groups of solid-phase processes, liquid-phase processes, and semisolid processes [6-9]. Eddy turbulence is utilized in most liquid state methods [10]. The in situ method is usually used for the production of aluminium matrix composites [11]. But the production of reinforcing particles in this method is difficult and costly and controlling the process is not easily. Ex situ enjoys advantages such as better bound of particle matrix, easier control of the matrix structure, easiness, and low cost of the process. However, it is difficult for mechanical turbulence process to distribute the microparticles evenly in the matrix while avoiding agglomeration or clustering due to high surface-to-volume ratio and low wetting in the molten metal. This reduces the percentage of the reinforcing particles in composite matrix. The goal of this research is to improve the wetting of alumina reinforcing particles by molten aluminium resulting in an increase in the volume percentage of aluminium reinforcing particles in $\mathrm{Al}-\mathrm{Al}_{2} \mathrm{O}_{3}$ casting composite matrix.

\section{Materials and Methods}

In this research, $99.5 \%$ pure aluminium powders and $99.8 \%$ pure alumina were used for milling operations. Figure 1 
TABLE 1: Chemical composition of waffle ingot use in the present research.

\begin{tabular}{lccccccccc}
\hline Element & $\mathrm{Mn}$ & $\mathrm{Cu}$ & $\mathrm{Zn}$ & $\mathrm{Si}$ & $\mathrm{Mg}$ & $\mathrm{Fe}$ & $\mathrm{Ti}$ & $\mathrm{Ni}$ & $\mathrm{Al}$ \\
\hline Weight percent & 0.003 & 0.021 & 0.004 & 0.150 & 0.002 & 0.263 & 0.006 & 0.004 & $\mathrm{Bal}$ \\
\hline
\end{tabular}

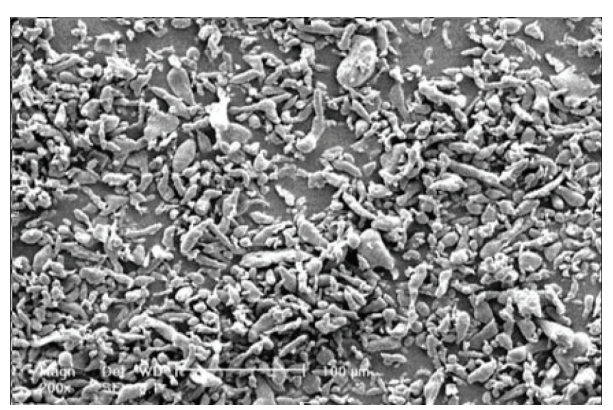

(a)

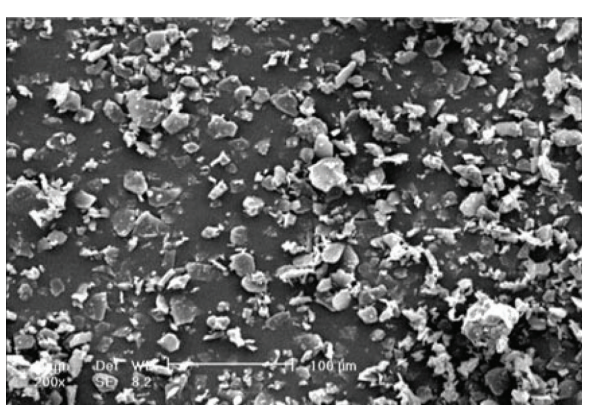

(b)

Figure 1: SEM images of (a) $\mathrm{Al}$ and (b) $\mathrm{Al}_{2} \mathrm{O}_{3}$.

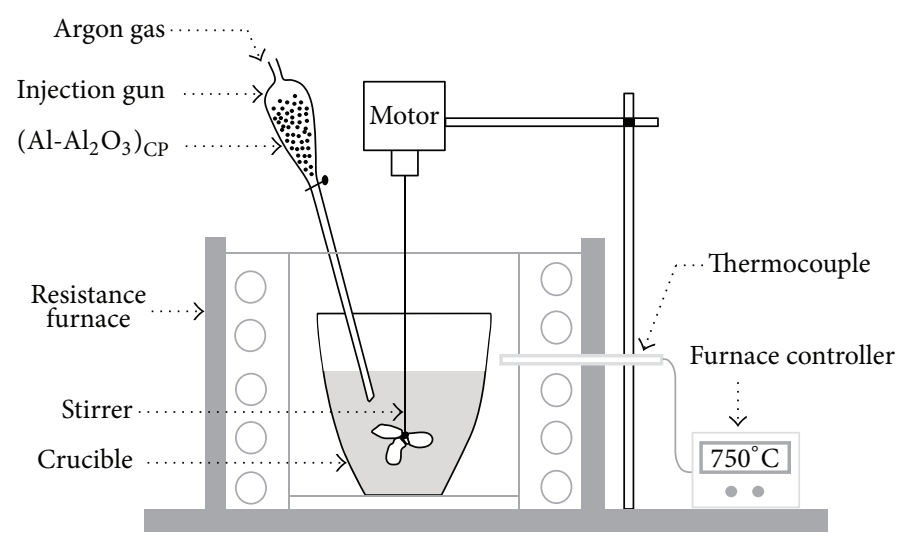

FIGURE 2: System for the injection of powdery composite capsules $\left(\mathrm{Al}-\mathrm{Al}_{2} \mathrm{O}_{3}\right)_{\mathrm{CP}}$ to aluminium melt.

depicts images of $\mathrm{Al}$ and $\mathrm{Al}_{2} \mathrm{O}_{3}$ powders by scanning electron microscope. The average sizes for aluminium and alumina powder particles were 29 and $45 \mu \mathrm{m}$, respectively.

Commercial pure waffle ingots were used as a composite matrix. Chemical composition of waffle ingots determined by quantometric method is depicted in Table 1.

For milling operations, aluminium and alumina powders were placed into a steel vial (with the capacity of 100 grams) by the weight ratio of 60 to 40 and by the ratio of 10 to 1 for ball to powder; then the vial was placed inside the planetary high-energy ball mill (Resteh, Pm 100) turning at $250 \mathrm{rpm}$.

Time duration for milling varied from 1,5 , to 10 hours. Then, the powdery composite capsules $\left(\mathrm{Al}-\mathrm{Al}_{2} \mathrm{O}_{3}\right)_{\mathrm{CP}}$ produced at the milling stage were added to aluminium melt and cast through ex situ method. The powdery composite capsules $\left(\mathrm{Al}-\mathrm{Al}_{2} \mathrm{O}_{3}\right)_{\mathrm{CP}}$ along with inert Argon gas (by the injection system depicted in Figure 2) were added to aluminium melt containing $3 \mathrm{wt} \% \mathrm{Mg}$ (for the improvement of the wetting degree of alumina particles with aluminium melt). While adding these capsules, the aluminium melt is stirred by graphite stirrer at $500 \mathrm{rpm}$. After adding the powder to the melt, it was cast into a steel mold at high cooling speed to obtain $\mathrm{Al}-\mathrm{Al}_{2} \mathrm{O}_{3}$ cast composite samples. An XL30 Scanning electron microscope was used to study the morphology of the capsules. Also, to study the microstructure of the produced composite, after grinding and polishing, the samples were etched by Keller solution and studied by a scanning electron microscope. Then, the image Tool software was used to measure the percentage of powdery composite capsules and the reinforcing particles present in the composite microstructure $\mathrm{Al}-\mathrm{Al}_{2} \mathrm{O}_{3}$ to obtain the optimum milling time.

The rate of wetting of alumina was determined by weighing of residual composite powder after casting. If the weight of primary powder is $W$ and weight of remaining powder is $M$, then the percentage of powder composite remaining in the aluminium melt has been calculated from this formula:

$$
\left(\mathrm{Al}-\mathrm{Al}_{2} \mathrm{O}_{3}\right)_{\mathrm{CP}} \%=\left(\frac{(W-M)}{W}\right) * 100
$$

To determine the mechanical behavior of the different materials as a function of reinforcement percentage, tensile test was conducted at a constant strain rate of $10^{-3} \mathrm{~s}^{-1}$ at room temperature (298 K). 


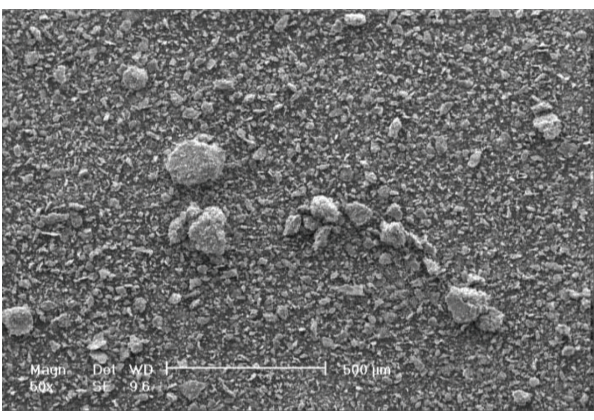

(a)

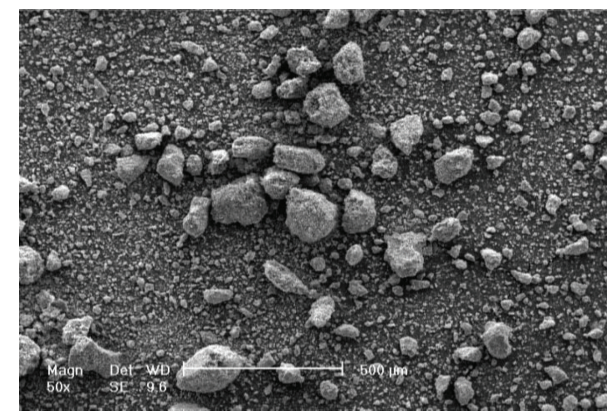

(b)

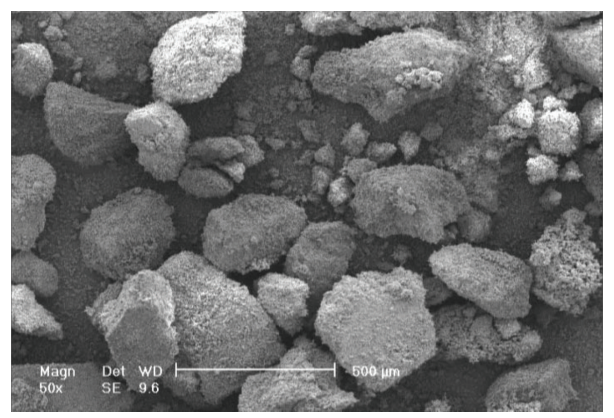

(c)

FIGURE 3: SEM images of powdery composite capsules for milling times (a) 1, (b) 5, and (c) 10 hours.

\section{Results and Discussion}

3.1. The Effect of Milling Time on the Size and Percentage of Powdery Composite Capsules. Figure 3 depicts the images of the powdery composite capsules by the scanning electronic microscope at different milling time durations. As it is observed, by an increase in milling time duration, the percentage and the size of $\left(\mathrm{Al}-\mathrm{Al}_{2} \mathrm{O}_{3}\right)_{\mathrm{CP}}$ powdery composite capsules also increase. The percentage of the formed powdery composite capsules, depicted in Figure 4, is measured by Image Tool software at different milling times.

The reason for an increase in the percentage and the size of powdery composite capsules is that, by an increase in milling time, the possibility of collision among the powder particles is increased [12]. Since there are only two types of alumina and aluminium powders in this system, three states are created by an increase in milling time. In the first state, there is the possibility of the collision among aluminium powder particles. In this state, the produced aluminium matrix in the powdery composite capsules gets larger, resulting in an increase in the size of the capsules. In the second state, there is greater possibility of the collision of alumina powdery particles with aluminium. In this state, a higher percentage of alumina particles collide with aluminium matrix and engulfed in it. As a result, the percentage of powdery composite capsules increases. In the third state the possibility of collision of alumina powder particles with each other is increased. Since the alumina particles are brittle and fragile at this stage, they break and become finer as the result of collision. Therefore, by an increase in milling time, finer particles of alumina are engulfed in aluminium matrix.

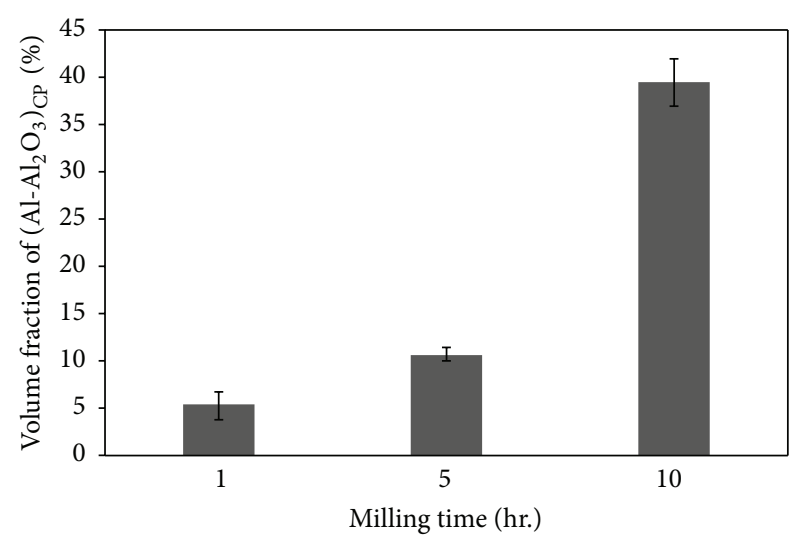

Figure 4: Percentage of powdery composite capsules formed for different times of milling.

This phenomenon results in an increase in the mechanical properties of the manufactured composite [13]. Figure 5 depicts the schematic of the abovementioned states and the effect of an increase in milling time on the capsule size and percentage of the produced $\mathrm{Al}_{2} \mathrm{O}_{3}$ in it. As it is shown in this figure, in addition to enlargement of aluminium matrix, the percentage of $\mathrm{Al}_{2} \mathrm{O}_{3}$ particles present in the matrix is also increased by an increase in milling time.

Figure 6 depicts the image of powdery composite capsules by scanning electron microscope for a 10-hour milling time (Figure 3(c)) at higher magnification. As it is observed, in addition to enlargement of aluminium matrix, its surface is also coated with alumina particles in this figure and the percentage of alumina particles in the matrix is dramatically 


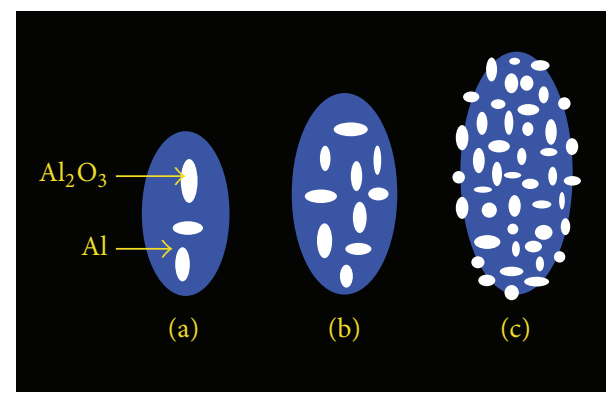

FIgURE 5: The effect of an increase in milling time on the size of capsule and percentage of $\mathrm{Al}_{2} \mathrm{O}_{3}$ produced in it.

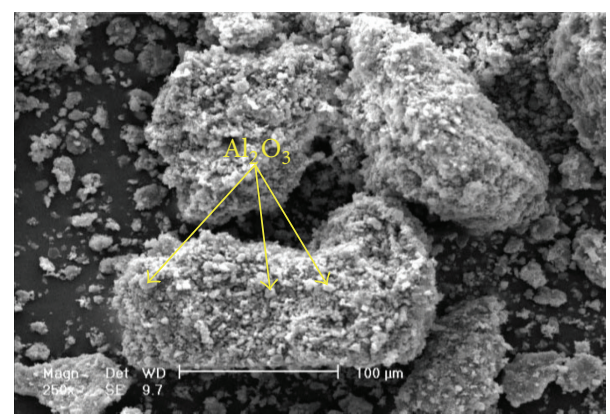

FIGURE 6: SEM image of powdery composite capsules for 10 hours of milling (Figure 3(c)) with higher magnification.

increased. This image confirms the schematic presented in Figure 5(c).

The same results were obtained when aluminium powder was milled by $\mathrm{Al}_{2} \mathrm{O}_{3}$ powder. The powder particle size is changing with milling time, as a result of the two opposing factors of cold welding and fracturing of powder articles [14].

\subsection{The Effect of Milling Time on the Percentage of the Reinforc-} ing Particles in Cast Composite. Figure 7 depicts the images of cast composite resulting from the produced capsules by scanning electron microscope at different milling times. Table 2 illustrates percentage of $\left(\mathrm{Al}-\mathrm{Al}_{2} \mathrm{O}_{3}\right)_{\mathrm{CP}}$ entangled in aluminium melt. Figure 8 shows the percentage of reinforcing particles in the matrix of these composites measured by Image Tool software. Figures 7 and 8 show that, by an increase in milling time from 1 to 5 hours, the volume percentage of reinforcing particles in the cast composite matrix is also increased, but by more increase in milling time up to 10 hours, this percentage is dramatically reduced and reaches the least value. While adding powdery composite capsules resulting from one hour of milling to aluminium melt, a small amount of these particles are coated with aluminium powder reducing the rate of wetting, because the percentage of reinforcing particles in the capsules is small (Figures 3(a) and 4). Therefore, in comparison with 5 hour-milled powder composites, the percentage of incorporated $\left(\mathrm{Al}-\mathrm{Al}_{2} \mathrm{O}_{3}\right)_{\mathrm{CP}}$ and reinforcing particles in the cast composite matrix is reduced (Figures 7(a), 8 and Table 2). By increasing the milling time to 10 hours, the greatest percentage of alumina reinforcing particles are engulfed in powdery composite capsules and
TABLE 2: Percentage of $\left(\mathrm{Al}-\mathrm{Al}_{2} \mathrm{O}_{3}\right)_{\mathrm{CP}}$ incorporated in aluminium melt for different milling times.

\begin{tabular}{|c|c|c|}
\hline Materials & $\begin{array}{l}\text { Milling time } \\
\text { (Hour) }\end{array}$ & $\begin{array}{c}\text { Incorporated }\left(\mathrm{Al}-\mathrm{Al}_{2} \mathrm{O}_{3}\right)_{\mathrm{CP}} \text { in } \\
\text { aluminium melt }\end{array}$ \\
\hline $\mathrm{Al}-8 \mathrm{wt} \% \mathrm{Al}_{2} \mathrm{O}_{3}$ & 1 & $16 \%$ \\
\hline $\mathrm{Al}-18 \mathrm{wt} \% \mathrm{Al}_{2} \mathrm{O}_{3}$ & 5 & $36 \%$ \\
\hline $\mathrm{Al}-6 \mathrm{wt} \% \mathrm{Al}_{2} \mathrm{O}_{3}$ & 10 & $12 \%$ \\
\hline
\end{tabular}

TABLE 3: Summary of mechanical deformation parameters of Al$\mathrm{Al}_{2} \mathrm{O}_{3} \mathrm{MMC}$.

\begin{tabular}{lcccc}
\hline Materials & $\begin{array}{c}\text { Milling time } \\
(\text { Hour })\end{array}$ & $S_{y}(\mathrm{MPa})$ & $S_{u}(\mathrm{MPa})$ & $\mathrm{El}(\%)$ \\
\hline $\mathrm{Al}-0 \mathrm{wt} \% \mathrm{Al}_{2} \mathrm{O}_{3}$ & 0 & 62 & 133.8 & 17.9 \\
$\mathrm{Al}-8 \mathrm{wt} \% \mathrm{Al}_{2} \mathrm{O}_{3}$ & 1 & 77.36 & 152.51 & 16.2 \\
$\mathrm{Al}-18 \mathrm{wt} \% \mathrm{Al}_{2} \mathrm{O}_{3}$ & 5 & 105.7 & 182.97 & 14.78 \\
$\mathrm{Al}-6 \mathrm{wt} \% \mathrm{Al}_{2} \mathrm{O}_{3}$ & 10 & 74.9 & 147.78 & 16.8 \\
\hline
\end{tabular}

the whole surface of these capsules is coated with reinforcing particles (Figures 4 and 6). Since the surface of these capsules is coated with alumina particles, when added to aluminium melt, the rate of wetting dramatically drops (Table 2) and these capsules are agglomerated rising to the surface of the melt or settled. Therefore, the percentage of reinforcing particles in the cast composite matrix is radically reduced (Figures 7(c) and 8). By optimization of the milling time to 5 hours, alumina particles are sufficiently placed in the capsule matrix and also, on the other hand, the alumina particles are properly coated by aluminium powder (Figure 3(b)). During the addition of these capsules to aluminium melt, the rate of the wetting of alumina particles significantly increases (Table 2) and ultimately the percentage of the reinforcing particles significantly increases in the cast composite matrix (Figures 7(b) and 8).

3.3. The Effect of Milling Time on Tensile Stress and Percentage Elongation. From the study of Table 3, it can be seen that, by surface modification and accordingly increasing percentage of $\mathrm{Al}_{2} \mathrm{O}_{3}$, the tensile strength increases and the tensile strength of the composites is higher than that of the matrix alloy. This improvement in tensile strength of the composites may be attributed to the fact that the particle $\mathrm{Al}_{2} \mathrm{O}_{3}$ possesses higher strength and also may be due to the better bonding strength due lower fineness of dispersed particulates. The same results were obtained when the aluminium matrix was reinforced with ceramic particulates [15-17].

Further it can be seen from Table 3 that the percentage elongation is decreasing with the increasing percentage of $\mathrm{Al}_{2} \mathrm{O}_{3}$ content. This is due to the higher brittleness of the reinforcing material. Hence, it is clear that the composite material is becoming more and more brittle as the $\mathrm{Al}_{2} \mathrm{O}_{3}$ content is increasing in the matrix material; in other words, the matrix material is losing its ductility due to the influence of the reinforcement material. 


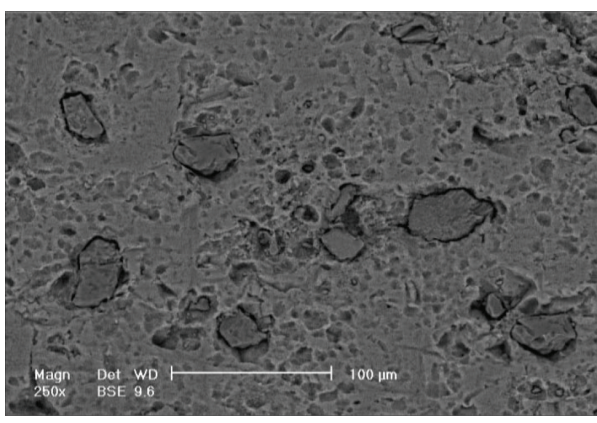

(a)

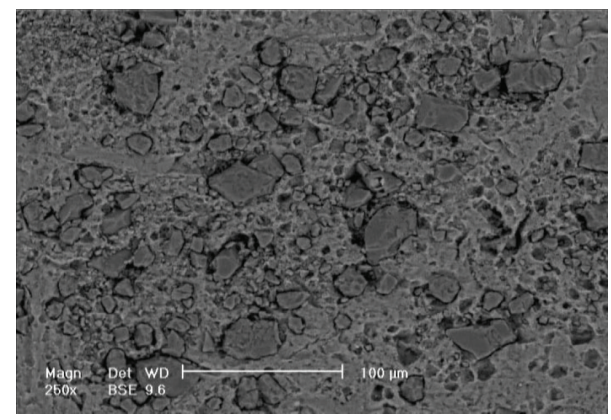

(b)

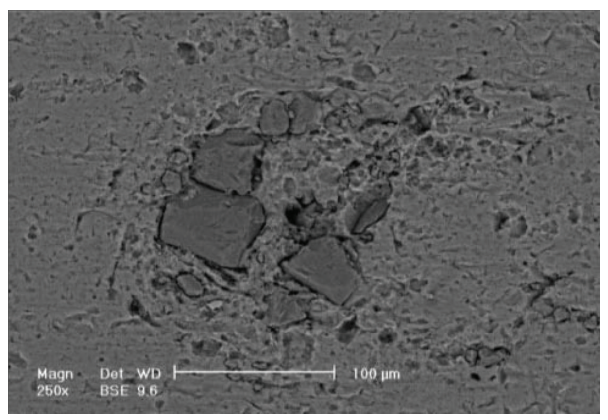

(c)

FIGURE 7: SEM images of cast composite prepared from capsules produced at milling hours (a) 1, (b) 5, and (c) 10 hours.

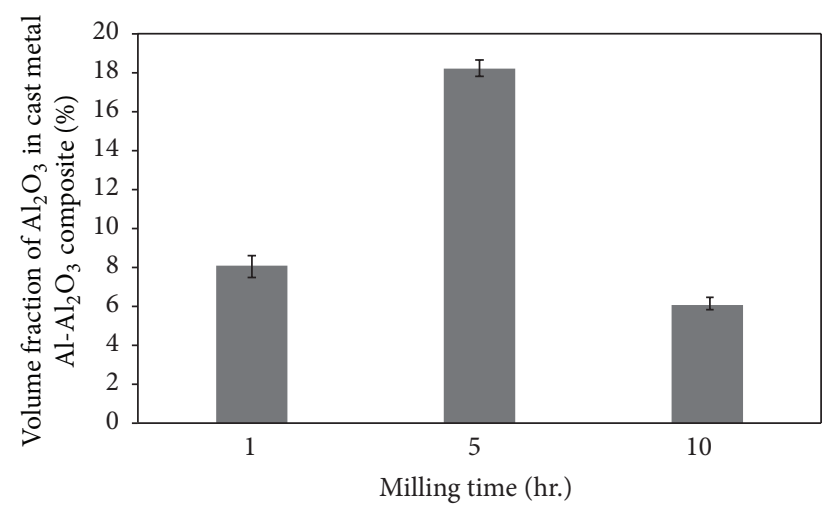

FIgURE 8: Percentage of reinforcing particles in cast composite matrix prepared from capsules produced at different milling times.

\section{Conclusion}

By increasing milling time from 1 to 5 hours, the volume percentage of reinforcing particles in the cast composite matrix increases, but by more increase in milling time up to 10 hours, this percentage is dramatically reduced. By optimizing the milling time to 5 hours, enough alumina particles are placed in the matrix of the capsules and also, on the other hand, the alumina particles are properly coated by aluminium powder. When these capsules are added to aluminium melt, the rate of wetting of alumina particles increases significantly and ultimately the percentage of reinforcing particles in the cast composite matrix also increases considerably. By increasing reinforcing particles, mechanical deformation parameters have substantially changed; in fact tensile strength raised sharply, whereas percentage elongation mildly plummeted.

\section{Conflict of Interests}

The authors declare that there is no conflict of interests regarding the publication of this paper.

\section{Acknowledgment}

The authors sincerely thank the laboratory staff of Department of Materials Sciences of Isfahan University of Technology.

\section{References}

[1] M. Kok, "Production and mechanical properties of $\mathrm{Al}_{2} \mathrm{O}_{3}$ particle-reinforced 2024 aluminium alloy composites," Journal of Materials Processing Technology, vol. 161, no. 3, pp. 381-387, 2005.

[2] M. Rahimian, N. Parvin, and N. Ehsani, "The effect of particle size, sintering temperature and sintering time on the properties of $\mathrm{Al}-\mathrm{Al}_{2} \mathrm{O}_{3}$ composites, made by powder metallurgy," Journal of Materials Design, vol. 32, pp. 1031-1038, 2011.

[3] M. Besterci and L. Kováć, "Microstructure and properties of $\mathrm{Cu}-\mathrm{Al}_{2} \mathrm{O}_{3}$ composites prepared by powder metallurgy," International Journal of Materials and Product Technology, vol. 18, no. 1-3, pp. 26-56, 2003.

[4] I. M. Hutchings, S. Wilson, and A. T. Alpas, Comprehensive Composite Materials, vol. 3, Elsevier Science, London, UK, 2000. 
[5] J. Scalon, N. R. J. Fieller, E. C. Stillman, and H. V. Atkinson, "A model-based analysis of particle size distributions in composite materials," Acta Materialia, vol. 51, no. 4, pp. 997-1006, 2003.

[6] P. K. Ghosh and S. Ray, "Fabrication and properties of compocast aluminium-alumina particulate composite," Indian Journal of Technology, vol. 26, no. 2, pp. 83-94, 1988.

[7] J. B. Fogagnolo, E. M. Ruiz-Navas, M. H. Robert, and J. M. Torralba, "The effects of mechanical alloying on the compressibility of aluminium matrix composite powder," Materials Science and Engineering A, vol. 355, no. 1-2, pp. 50-55, 2003.

[8] J. B. Fogagnolo, F. Velasco, M. H. Robert, and J. M. Torralba, "Effect of mechanical alloying on the morphology, microstructure and properties of aluminium matrix composite powders," Materials Science and Engineering A, vol. 342, no. 1-2, pp. 131143, 2003.

[9] L. E. G. Cambronero, E. Sánchez, J. M. Ruiz-Roman, and J. M. Ruiz-Prieto, "Mechanical characterisation of AA7015 aluminium alloy reinforced with ceramics," Journal of Materials Processing Technology, vol. 143-144, no. 1, pp. 378-383, 2003.

[10] P. K. Ghosh, S. Ray, and P. K. Rohatgi, "Incorporation of alumina particles in aluminium-magnesium alloy by stirring in melt," Transactions of the Japan Institute of Metals, vol. 25, no. 6, pp. 440-444, 1984.

[11] K. D. Woo and H. B. Lee, "Fabrication of $\mathrm{Al}$ alloy matrix composite reinforced with subsive-sized $\mathrm{Al}_{2} \mathrm{O}_{3}$ particles by the in situ displacement reaction using high-energy ball-milled powder," Materials Science and Engineering A, vol. 449-451, pp. 829-832, 2007.

[12] C. Suryanarayana, "Mechanical alloying and milling," Progress in Materials Science, vol. 46, no. 1-2, pp. 1-184, 2001.

[13] S. H. Chen and T. C. Wang, "Size effects in the particlereinforced metal-matrix composites," Acta Mechanica, vol. 157, no. 1-4, pp. 113-127, 2002.

[14] B. Prabhu, C. Suryanarayana, L. An, and R. Vaidyanathan, "Synthesis and characterization of high volume fraction $\mathrm{Al}^{-\mathrm{Al}_{2} \mathrm{O}_{3}}$ nanocomposite powders by high-energy milling," Materials Science and Engineering A, vol. 425, no. 1-2, pp. 192-200, 2006.

[15] M. R. Rosenberger, C. E. Schvezov, and E. Forlerer, "Wear of different aluminum matrix composites under conditions that generate a mechanically mixed layer," Wear, vol. 259, no. 1-6, pp. 590-601, 2005.

[16] L. J. Yang, "Wear coefficient equation for aluminium-based matrix composites against steel disc," Wear, vol. 255, no. 1-6, pp. 579-592, 2003.

[17] N. Altinkok and R. Koker, "Modelling of the prediction of tensile and density properties in particle reinforced metal matrix composites by using neural networks," Materials and Design, vol. 27, no. 8, pp. 625-631, 2006. 

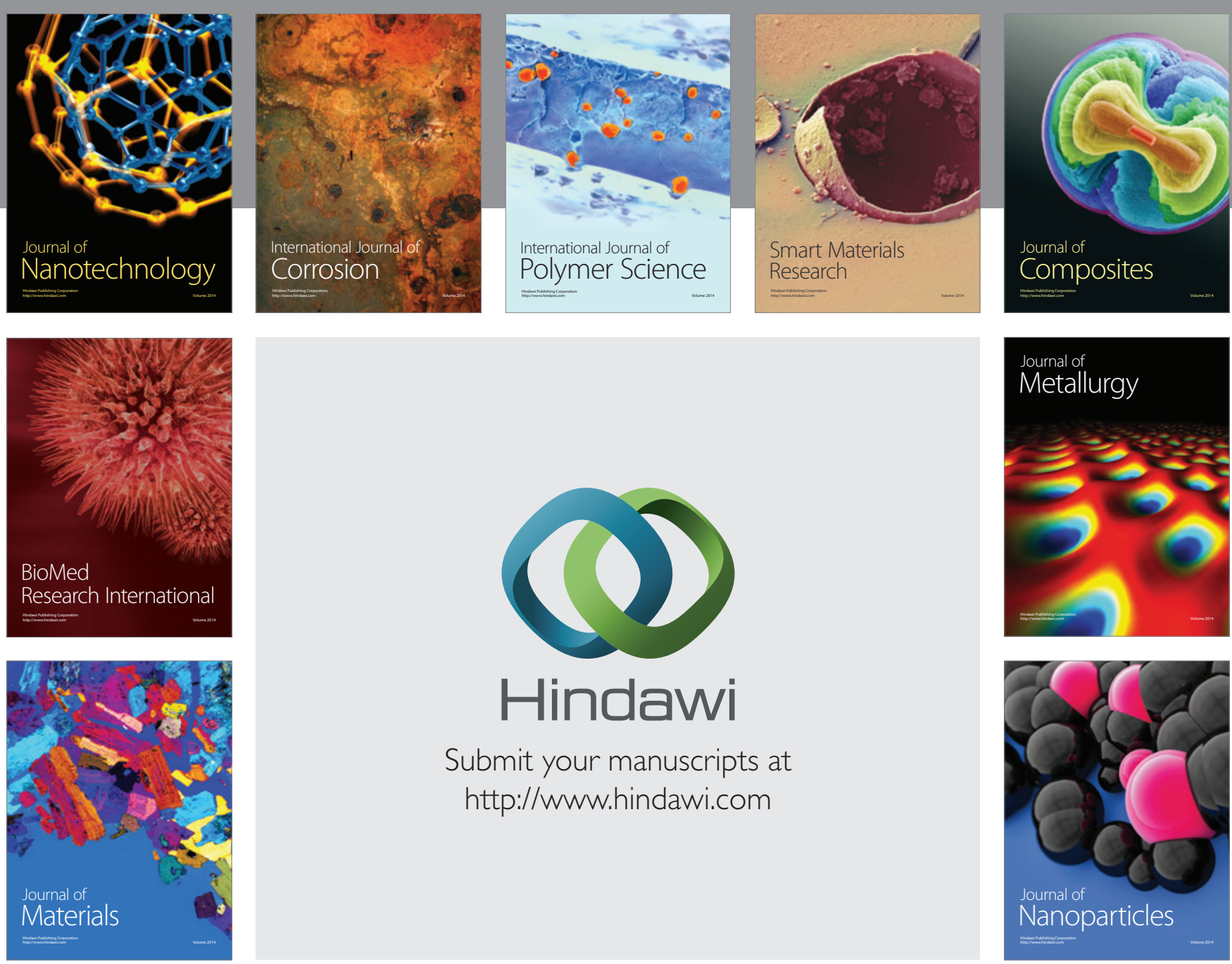

Submit your manuscripts at http://www.hindawi.com
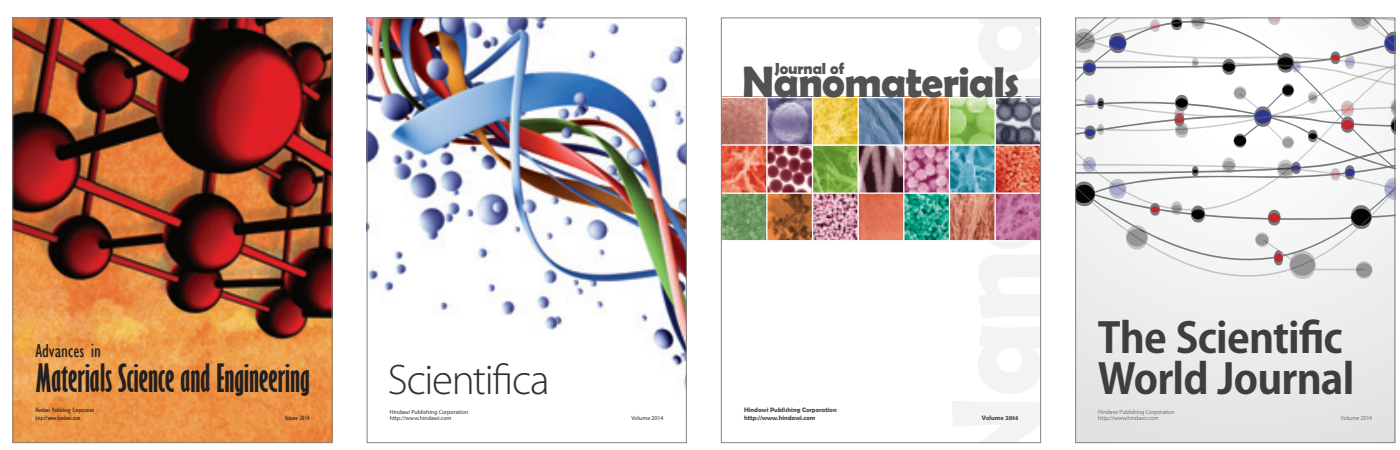

\section{The Scientific World Journal}
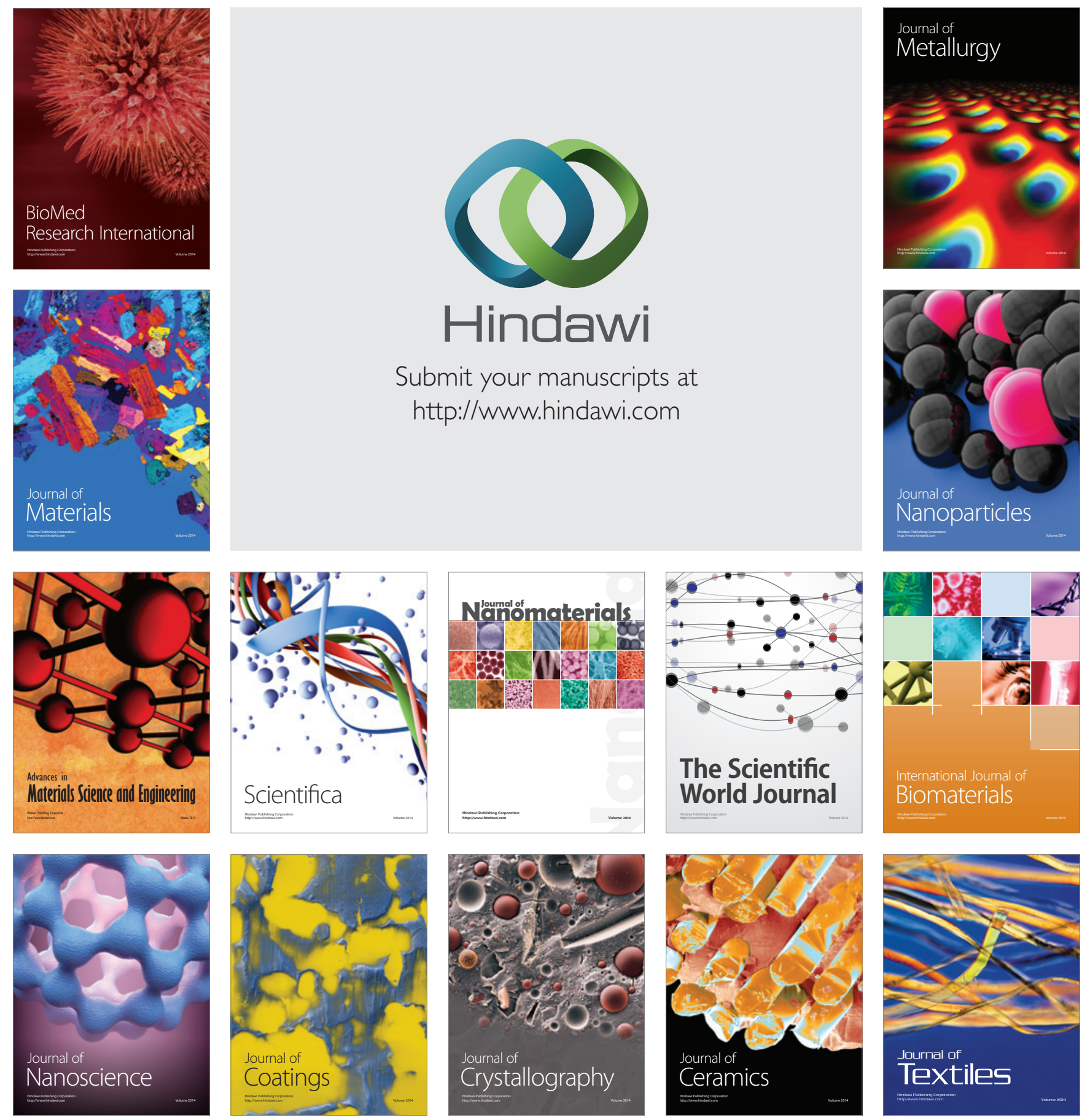